Review

\title{
Vitamin E: A Review of Its Application and Methods of Detection When Combined with Implant Biomaterials
}

\author{
Francesca Gamna * and Silvia Spriano \\ Department of Applied Science and Technology, Politecnico di Torino, 10129 Torino, Italy; silvia.spriano@polito.it \\ * Correspondence: francesca.gamna@polito.it
}

\begin{abstract}
Vitamin E is a common compound used for tocopherols and tocotrienols $(\alpha, \beta, \gamma, \delta)$; it is the component of many natural products of both plant and animal origin. Thanks to its powerful antioxidant capacity, vitamin E has been very successful in hip and knee arthroplasty, used to confer resistance to oxidation to irradiated UHMWPE. The positive results of these studies have made vitamin $\mathrm{E}$ an important object of research in the biomedical field, highlighting other important properties, such as anti-bacterial, -inflammatory, and -cancer activities. In fact, there is an extensive literature dealing with vitamin $\mathrm{E}$ in different kinds of material processing, drug delivery, and development of surface coatings. Vitamin $\mathrm{E}$ is widely discussed in the literature, and it is possible to find many reviews that discuss the biological role of vitamin $\mathrm{E}$ and its applications in food packaging and cosmetics. However, to date, there is not a review that discusses the biomedical applications of vitamin $\mathrm{E}$ and that points to the methods used to detect it within a solid. This review specifically aims to compile research about new biomedical applications of vitamin E carried out in the last 20 years, with the intention of providing an overview of the methodologies used to combine it with implantable biomaterials, as well as to detect and characterize it within these materials.
\end{abstract}

Citation: Gamna, F.; Spriano, S.

Vitamin E: A Review of Its

Application and Methods of

Detection When Combined with

Implant Biomaterials. Materials 2021,

14, 3691. https://doi.org/10.3390/

ma14133691

Academic Editor: Silvie Rimpelová

Received: 17 May 2021

Accepted: 29 June 2021

Published: 1 July 2021

Publisher's Note: MDPI stays neutral with regard to jurisdictional claims in published maps and institutional affiliations.

\section{Introduction}

\subsection{Structure of Vitamin E}

Vitamin E was first discovered and described by Evans and Bishop in 1922; it includes eight natural forms ( $\alpha, \beta, \gamma, \delta$; tocopherols and tocotrienols), and it can be found in various products bearing fats of both vegetable and animal origin, such as in olive or almond oil, hazelnuts, and egg yolk, and in the liver. Basically, tocopherols and tocotrienols have the same chemical structure, characterized by a 16-carbon lateral chain attached to position 2 of a benzopyran ring. The two isoforms differ substantially from the saturation of the long radical chain: tocopherols have a fully saturated chain, while tocotrienols have an unsaturated chain. As Figure 1 explains, the two homologs were named according to the position and number of the methyl group bound to the phenolic ring [1-3].

Among all the isoforms of vitamin E, $\alpha$-tocopherol is the most abundant in the blood, because it is the only one that is absorbed within the body, while the other isoforms are excreted through the intestine. The liver, which takes up nutrients after they are absorbed by the small intestine, absorbs vitamin $\mathrm{E}$ thanks to the plasmatic lipoproteins that function as carriers. Among all the various forms of the vitamin E, alpha-tocopherol is re-secreted through the liver protein of $\alpha$-tocopherol transfer ( $\alpha$-TTP) and distributed to circulating lipoproteins (LDL, IDL, VLDL). The other forms are metabolized and then expelled through the intestine (Figure 2) [4]. 


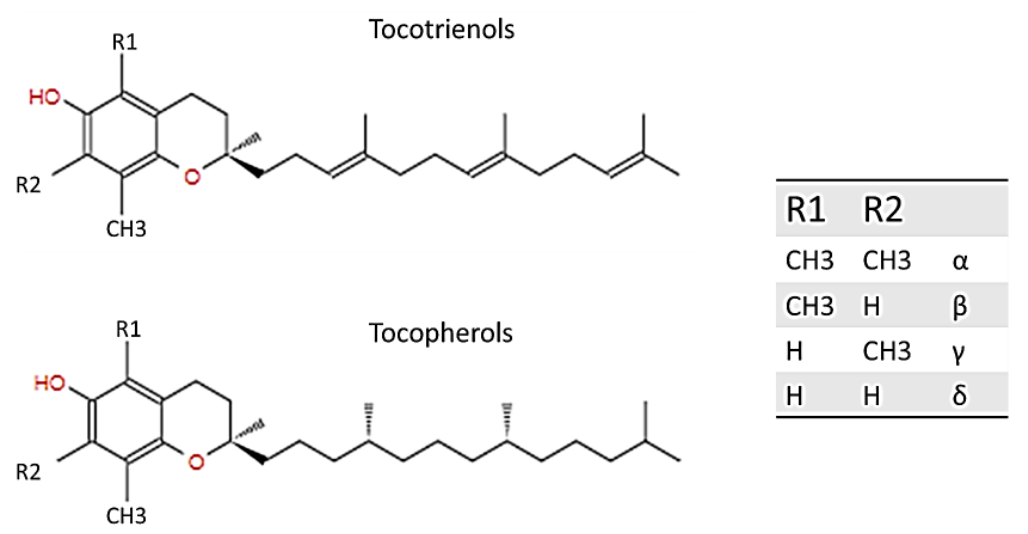

Figure 1. Structure of tocotrienol and tocopherol.

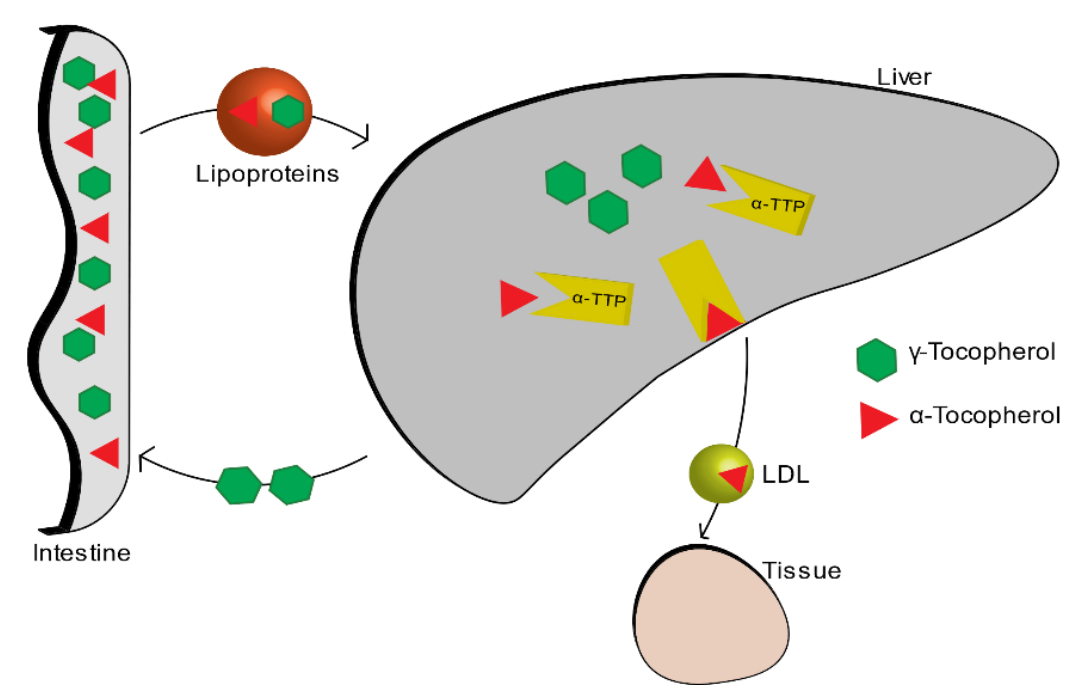

Figure 2. Vitamin E metabolism.

\subsection{Biological Role of Vitamin $E$}

Alpha-tocopherol is a phenolic antioxidant. The scavenging mechanism involves the donation of hydrogen from the hydroxyl group $(-\mathrm{OH})$ of the phenolic ring to free radicals (ROS). In this way, the free radicals become unreactive and unable to do any more damage. After this reaction, also the phenolic compound itself becomes relatively unreactive with a higher stability. Its stability is guaranteed by the now unpaired electron which is on the oxygen atom and which is delocalized in the structure of the aromatic ring. $\alpha$-tocopherol is located within the phospholipid membrane of the cell, and it occurs with the radical chain embedded in the hydrophobic core of the double layer [5]. Its concentration, compared to the lipids present in the membrane, is very low, but in spite of this, it plays an important role in preserving the integrity of the membrane by preventing lipid peroxidation which causes damage of cellular membranes, lipoproteins, and other molecules that contain lipids, in conditions of oxidative stress $[1,6,7]$.

Oxidative stress is a pathological condition caused by the imbalance between the generation and elimination of chemical oxidant species (ROS), and it is involved in several neurodegenerative diseases such as Alzheimer's and Parkinson's disease that are implicated in free radical processes and oxidative damage [8]. That said, it is easy to think of vitamin $\mathrm{E}$ that, thanks to its important qualities as an antioxidant, may have an important role in the integrity of the brain. To confirm this, a high level of $\alpha$-TTP was found in the brain [9].

Vitamin $\mathrm{E}$ is an important anti-inflammatory molecule since it acts on many different factors that affect, directly or indirectly, the immune system. Vitamin E is able to modulate 


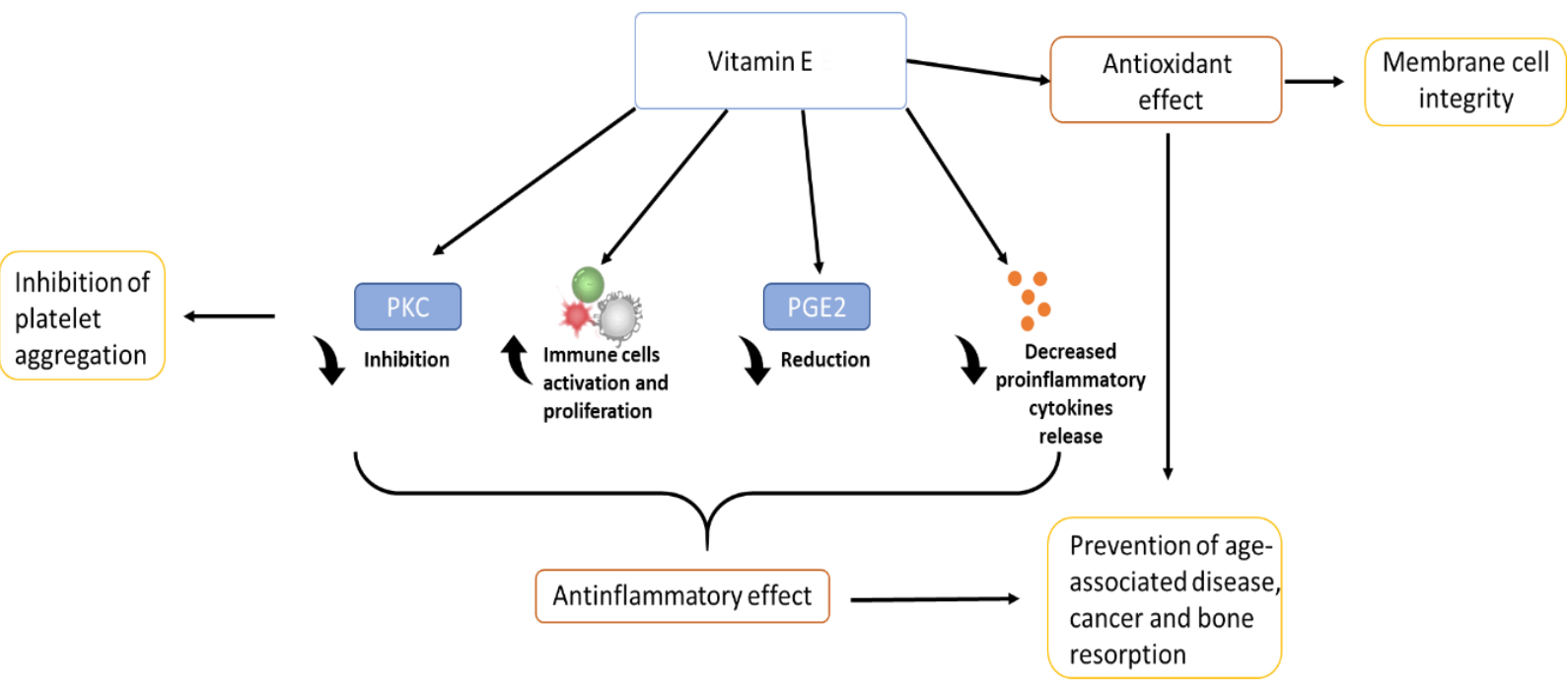

inflammation through different ways: it has effect on proinflammatory enzymes such as COX, responsible for prostaglandins (PG)E $\mathrm{E}_{2}$ production [10,11]; $(\mathrm{PG}) \mathrm{E} 2$ is a proinflammatory mediator that has been associated with several senility-related diseases such as cancer, arthritis, and cardiovascular diseases $[4,7,12])$. It modulates the proliferation and activation of certain cells of the immune system such as T cells, lymphocytes, and NK cells [13]. Finally, it acts on the secretion of proinflammatory cytokines such as IL-6 and TNF- $\alpha$. Thanks to these factors, vitamin E plays an important role in helping to prevent chronic inflammation [11,13]. Chronic inflammation is strictly linked to oxidative stress [14] and, together with it, it is the main cause of age-related disease and cancer [11].

Vitamin $\mathrm{E}$ has also an important role in the inhibition of platelet aggregation, inhibiting various enzymes such as PKC, which is a key signal transduction pathway in several cell types $[1,15] . \alpha$-tocopherol, thanks to its free-radical scavenging and anti-inflammatory properties, has a benefit also in dermatology: it protects the skin from UV radiation, and accelerates the wound healing process after an injury such as ulcers or burns [16]. Inflammation could be associated also to a large number of different phenomena related to bone health: it is thought that thanks to its anti-inflammatory action and regulation of cytokine secretion, vitamin $\mathrm{E}$ can influence bone remodelling, being able to protect the bone against osteoclastic activity, increasing osteoblasts differentiation, and protecting cartilage health [17-19]. In addition, recent studies have shown that vitamin $E$ also has biomechanical effects, being able to increase specific characteristics such as load and yield [20]. Together with all these considerations, vitamin E, due to its antioxidant function, role in anti-inflammatory processes, inhibition of platelet aggregation, and immune systemenhancing activity [1,9], brings a wide range of benefits, from anti-cancer effects [21] to the prevention of disease progression, and in improving quality of life in the elderly [22]. The figure below (Figure 3) shows a schematic representation of the biological role of vitamin E.

Figure 3. Biological role of vitamin E.

More controversial and still under study, is the anti-bacterial role of vitamin E. In the literature, it is possible to find vitamin $\mathrm{E}$ used as a natural compound to treat infections caused by specific Gram-positive or negative bacteria $[23,24]$ or as an antibiotic adjuvant used in combination with antibiotics for the treatment of infections [25,26]. Moreover, the addition of vitamin $\mathrm{E}$ to materials may have the ability to reduce biofilm formation on the surface. As the literature suggests, it is possible to believe that tocopherol is able to reduce the biofilm formation capacity of a big range of strains (S. aureus and S. epidermidis, etc.), regardless of the classification of the bacterium (Gram-negative or -positive) [27]. This, however, comes into opposition with other studies that show instead that vitamin $\mathrm{E}$, in composition with other materials, did not reduce biofilm formation [28]. 
Once the biological role of vitamin $\mathrm{E}$ is understood, it is certainly interesting to analyse its application and detection methods, when it is combined to a biomaterial. Over the past 20 years, there has been a strong increase in interest in scientific research on $\alpha$-tocopherol combined with various biomaterials (Figure 4). This review selected about 100 reviews best suited to the topic discussed.

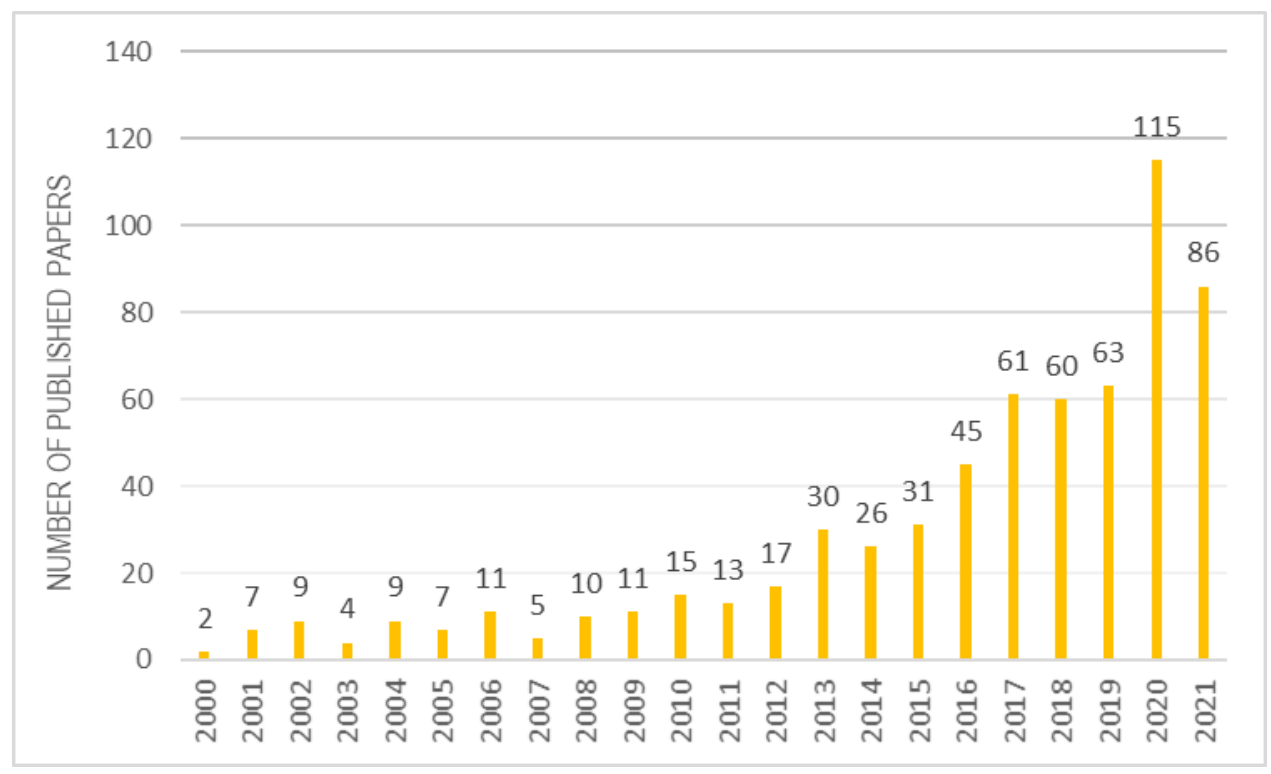

Figure 4. Studies inherent to $\alpha$-tocopherol combined with biomaterials over the years.

\section{Biomedical Applications of Vitamin E}

\subsection{Vitamin E in Prosthetic Implants}

Vitamin E is being researched as a molecule incorporated or used as a coating on prosthetic materials with the aim of creating implants with additional properties.

\subsubsection{Vitamin E in Blend Form or through Bulk Diffusion}

So far, the most successful application of $\alpha$-tocopherol has been the use as antioxidant to stabilize high molecular weight polyethylene (UHWMPE), which has made vitamin E a useful compound in the biomedical field. Until the late 1990s, prior to implantation, UHWMPE inserts were sterilized with gamma rays. Unfortunately, this type of sterilization carried a major oxidative problem for the polymer, since the radiation increases the possibility of oxidative degradation, making it more unstable and fragile, leading to severe implant loosening phenomena $[25,27]$. The incorporation into the polymer of antioxidants such as tocopherols was considered to overcome this problem. This idea was born from the use of vitamin $\mathrm{E}$ in food packaging industries as an antioxidant of polyolefins [29,30]. For the incorporation phase, $\alpha$-tocopherol is typically inserted into the material before sterilization in two ways, before (creating the VE-UHMWPE blend) or after crosslinking irradiation (through bulk diffusion) [31-33]. The success of this new material in the biomedical field is guaranteed by the very good biocompatibility of vitamin $\mathrm{E}$ which has been proven not to have cytotoxic effects [25]. After the use of alpha-tocopherol combined with UHWMPE, new combinations with other biomaterials have been pursued and are still under study.

\subsubsection{Vitamin $\mathrm{E}$ as a Coating}

One of the most common concerns of biomedical implants is the problem of joint replacement because of loosening. Causes of failure include infections and wear, which could cause chronic inflammation by the presence of debris originating in the articular part of the prosthesis. A coating able to have an anti-inflammatory and anti-bacterial action can certainly help to reduce these events, consequently reducing the phenomena of septic or 
aseptic loosening of the prostheses. For this reason, although still in the research phase, some works suggest the use of vitamin E for coating metal surfaces with the aim of providing anti-bacterial and anti-inflammatory properties or to help osseointegration [34-37]. These studies employed pure titanium as a substrate, which is a biomaterial commonly used in dental, cranial, and joint implants. As later shown in Table 1, the coatings are created by the adsorption of vitamin $\mathrm{E}$ on the metal surfaces by leaving the samples in the vitamin solution. Given the high hydrophobicity of vitamin E, in all cases the solvent used during the coating formation is ethanol. Then, the biological response (in vitro and in vivo) of the titanium implants coated with vitamin $\mathrm{E}$ has been evaluated. Bidossi et al. made interesting studies on the anti-microbial activity, creating coatings on pure titanium surfaces, using two different forms of vitamin E: $\alpha$-tocopherol acetate and $\alpha$-tocopherol phosphate, derived from the esterification of $\alpha$-tocopherol with the acetate group and the phosphate group, respectively. It was found that especially tocopherol phosphate is anti-microbial against both Gram-positive and Gram-negative, and it also has the ability to stimulate osteoblasts, finding many applications in the implant field [31,34]. Maria Satuè et al. used vitamin $\mathrm{E}$ as an antioxidant, recalling its main ability that protects the 7-DHC molecule; this molecule during UV irradiation is activated, becoming a precursor of vitamin $\mathrm{D}$, and it is employed as a coating on pure titanium surfaces [33,34].

Table 1. Vitamin E in Prosthetic devices.

\begin{tabular}{|c|c|c|c|c|c|c|}
\hline Material & Molecule & Combination & Method of Combination & Results & Application & Ref. \\
\hline \multirow[t]{2}{*}{ UHWMPE } & \multirow[t]{2}{*}{$\alpha$-Тoc } & \multirow[t]{2}{*}{ Blending } & $\begin{array}{l}\text { 1: Blending of vitamin E } \\
\text { with UHMWPE resin } \\
\text { powder and following } \\
\text { irradiation for } \\
\text { crosslinking }\end{array}$ & \multirow{2}{*}{$\begin{array}{l}\text { Vitamin E is able to } \\
\text { prevent oxidation during } \\
\text { gamma sterilization of } \\
\text { UHWMPE. }\end{array}$} & \multirow[t]{2}{*}{ Material stabilizer } & \multirow[t]{2}{*}[31-33]{} \\
\hline & & & $\begin{array}{l}\text { 2: Vitamin } \mathrm{E} \text { is diffused } \\
\text { into an already } \\
\text { crosslinked UHWMPE }\end{array}$ & & & \\
\hline \multirow{3}{*}{ Pure Titanium } & $\begin{array}{l}\alpha \text {-toc }+ \\
7-\mathrm{DHC}\end{array}$ & Coating & $\begin{array}{c}\text { Preparation of a solution } \\
\text { of } 7-\mathrm{DHC}+\text { tocopherol } \\
\text { (1:1) in ethanol } 10 \mu \mathrm{L} \text { of } \\
\text { the prepared solution left } \\
\text { on the surface and further } \\
\text { UV-irradiated and } \\
\text { incubate for } 48 \mathrm{~h} \text { at } 23^{\circ} \mathrm{C}\end{array}$ & $\begin{array}{l}\text { Vitamin E is able to } \\
\text { protect 7-DHC from } \\
\text { oxidation during } \\
\text { UV-irradiation; vitamin E } \\
\text { helps osseointegration of } \\
\text { the coated samples both } \\
\text { in vivo and in vitro. }\end{array}$ & Molecule stabilizer & {$[35,36]$} \\
\hline & $\begin{array}{c}\alpha \text {-toc } \\
\text { Acetate }\end{array}$ & Coating & $\begin{array}{l}\text { Spreading of the solution } \\
\text { of } \alpha \text {-toc Acetate in ethanol } \\
(500 \mathrm{mg} / \mathrm{mL}) \text { on a } \\
\text { sandblasted disk of } \\
\text { titanium. }\end{array}$ & $\begin{array}{l}\text { Low anti-microbial } \\
\text { activity shown in vitro in } \\
\text { part against } S \text {. aureus and } \\
\text { S. epidermidis. }\end{array}$ & $\begin{array}{l}\text { Coating for implants } \\
\text { in order to prevent } \\
\text { implant-associated } \\
\text { infections }\end{array}$ & {$[34]$} \\
\hline & $\begin{array}{c}\alpha \text {-toc } \\
\text { Phosphate }\end{array}$ & Coating & 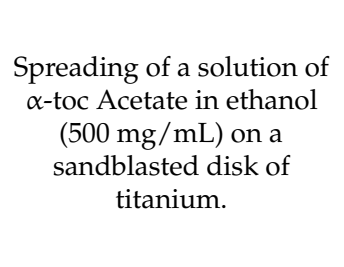 & $\begin{array}{c}\text { Good anti-microbial } \\
\text { activity shown in vitro } \\
\text { against every strain } \\
\text { (S. aureus and } S . \\
\text { epidermidis, } P \text {. aeruginosa, } P \text {. } \\
\text { acnes). Good bone } \\
\text { stimulation shown } \\
\text { in vivo. }\end{array}$ & $\begin{array}{l}\text { Coatings for dental } \\
\text { implant in order to } \\
\text { prevent } \\
\text { implant-associated } \\
\text { infections and help } \\
\text { osseointegration }\end{array}$ & {$[34,37]$} \\
\hline
\end{tabular}

\subsection{Vitamin E in Tissue Engineering}

Thanks to its antioxidant and anti-inflammatory ability, $\alpha$-tocopherol has become an interesting object of research in the world of wound healing and tissue regeneration. In the literature, vitamin E can be found combined, encapsulated, or blended with different types of polymeric materials treated either as scaffolds, hydrogels, or films. 


\subsubsection{Vitamin E in Wound Healing}

Wound healing is a physiological process to maintain and achieve skin integrity after an injury such as a laceration or burn. Wound healing is a complicated and timeconsuming process, as it consists of the following steps: inflammation, proliferation, and maturation [38,39]. Combining vitamin $\mathrm{E}$ with polymers typically used in biomedicine, it is possible to obtain polymeric wound dressing that harnesses the antioxidant capabilities of vitamin E, so as to help and accelerate the healing process. For complete skin regeneration, the preferred dressing media are hydrogels and scaffolds, as they are threedimensional and facilitate cell attachment and growth. In the biomedical field, from tissue engineering to drug delivery, biopolymers commonly used are biodegradable polyesters, especially poly-e-caprolactone (PCL), poly(lactide) (PLA), and poly(lactide-co-glicolide) (PLGA). These materials ensure biocompatibility, biodegradability, and good mechanical performances. Polysaccharides, including chitosan, hyaluronic acid, and cellulose, in addition to having good biocompatibility and many hydrolysable groups, also have a structure that mimics the extracellular matrix (ECM). Chitosan hydrogel is an example of a perfect biomaterial for wound dressing; in fact, Arian Ehterami et al. prepared and tested chitosan/alginate hydrogel loaded with vitamin $\mathrm{E}$ for dorsal skin wound healing in a rat model that ensured epidermal cell proliferation with even a new generation of hair follicles, promising successful wound healing [40]. As mentioned, in addition to hydrogels, scaffolds are widely used for this purpose. However, the use of polyesters, typically with better mechanical performance than polysaccharides, may not provide a favourable surface for cell attachment. In fact, Chinnasamy Gandhimathi et al. produced PLA-CL nanofiber scaffolds, through electrospinning, and incorporated silk fibroin to enhance cell adhesion and vitamin $\mathrm{E}$ to provide a low-stress environment for cells. The created scaffolds were able to induce fibroblast proliferation and collagen secretion [41]. Saba Zahid et al. instead thought of using the two biomaterials, but for obtaining two layers, one of porous PCL and the other one of PLA film incorporating vitamin E; in this way, they were able to obtain a bilayer of electrospun nanofibers that supports cell proliferation and also angiogenesis [42] On the other hand, polysaccharide scaffolds do not present the above problem: electrospun cellulose acetate mats loaded with vitamin E prove effective for dermal therapy due to greater flexibility and good vitamin E release kinetics [43].

In addition to three-dimensional structures, polymeric films can be more easily obtained to aid wound healing. Gabriela Garrastazu Pereira et al. selected two polysaccharides, hyaluronic acid, and sodium alginate to create a polymeric film loaded with vitamin E acetate and aloe vera, characterizing it both mechanically and chemically [44]. Similarly, Sonia Trombino et al. prepared a collagen film esterified with $\alpha$-tocopherol (collagen $\alpha$-Tocopherulate) for wound-healing applications, exploiting the antioxidant capacity of the molecule [45].

\subsubsection{Vitamin $\mathrm{E}$ in Tissue Regeneration}

Tissue repair refers to the compensatory regeneration of a tissue, resulting in restoration of tissue structure and function. Tissues can be repaired by implanting structures, preferably three-dimensional, such as scaffolds that are able to stimulate cell proliferation and adhesion for complete tissue regeneration [46]. In this context, the same materials as above are used, which can support the tissue both mechanically and at the cellular level, and after doing their job are able to degrade in a physiological environment. Generally, polymers with good mechanical properties are used for hard tissues, while for soft tissues such as the cardiac one, a high mechanical performance is not required.

For example, Poly(3-hydroxybutyrate) $(\mathrm{P}(3 \mathrm{HB}))$ and bioactive glass are shown to have favourable properties for hard tissue regeneration. Superb K. Misra et al. created a Poly(3hydroxybutyrate) $(\mathrm{P}(3 \mathrm{HB}))$ /bioactive glass scaffold, adding vitamin $\mathrm{E}$ as an antioxidant capable to enhance protein adsorption [47]. Instead, contrary to what they expected, Filippo Renò et al. prepared PLA films blended with vitamin E which induce a reduction in osteoblast cell attachment and spreading [48]. This research team has published many 
works on these films. Their studies reveal that vitamin E confers important characteristics to the PLA surface: anti-adhesion for bacteria, more hydrophilic and therefore higher protein adsorption, and anti-adhesion for osteblasts, obtaining a new type of polymer that can be used in tissue engineering with several biological effects [48-50]. Besides a biological role, vitamin $\mathrm{E}$ also has a role in sustaining and adhering two different materials: Iulian Antoniac et al. created PLA-Mg composites as a filament for biomedical applications and used vitamin $E$ to enhance the adhesion between magnesium and PLA [51]. Instead, Zahra Mahdieh et al. employed vitamin E to protect starch, a biodegradable polysaccharide with low mechanical performance, from oxidation during the blending process at an elevated temperature [52].

For soft tissues, Youyang Qu et al. prepared alpha-tocopherol liposome loaded in chitosan hydrogel. $\alpha$-tocopherol was entrapped in a liposomal carrier, and the liposome was formulated into a chitosan-based hydrogel, with the aim of creating injectable engineered cardiac tissue capable of suppressing oxidative stress in the microenvironment, supporting and surviving cardiomyocytes [53]. Due to the hydrophobic nature of vitamin $\mathrm{E}$, it is always a bit of a struggle to insert it into polymers that are typically hydrophilic because they need to be hydrolysable. Table 2 reports in more detail methods of loading vitamin $\mathrm{E}$ in different biomaterials for tissue engineering applications and each biological response. As it can be seen, vitamin E can be inserted within the dressing through two ways: inserted directly within the solution, creating a homogenous mixture, which is then electrospun, gelled, or polymerized, or inserted within nanocarriers that are then in turn inserted within the biomaterial.

Table 2. Vitamin E in Tissue Engineering.

\begin{tabular}{|c|c|c|c|c|c|c|c|c|}
\hline $\begin{array}{l}\text { Polymer } \\
\text { Class }\end{array}$ & $\begin{array}{l}\text { Polymer } \\
\text { Name }\end{array}$ & Molecule & Structure & Method Loading & Biological Response & $\begin{array}{c}\text { Role of } \\
\text { Vitamin E }\end{array}$ & Applications & Ref. \\
\hline \multirow{5}{*}{ Polyesters } & PLA-Mg & $\alpha$-toc & Filaments & $\begin{array}{l}\text { Addition of Vitamin E in a } \\
\text { PLA-Mg solution before } \\
\text { the extrusion process and } \\
\text { following 3D printing of } \\
\text { the implant }\end{array}$ & Not reported & $\begin{array}{l}\text { It enhances } \\
\text { adhesion } \\
\text { between } \mathrm{Mg} \\
\text { particles and } \\
\text { PLA }\end{array}$ & $\begin{array}{l}\text { Implant } \\
\text { devices }\end{array}$ & [51] \\
\hline & PLA & $\alpha$-toc & $\begin{array}{l}\text { Polymeric } \\
\text { film }\end{array}$ & $\begin{array}{l}\text { Addition of Vitamin E into } \\
\text { the PLA/ chlorophorm } \\
\text { solution. Shaking of the } \\
\text { solution with following } \\
\text { addition of it in glass } \\
\text { dishes. } \\
\text { Evaporation of the solvent } \\
\text { in dark conditions at room } \\
\text { temperature. }\end{array}$ & $\begin{array}{l}\text { The film has good } \\
\text { protein adsorption; } \\
\text { inhibits osteoblasts, } \\
\text { bacterial, and } \\
\text { platelets adhesion } \\
\text { and spreading. }\end{array}$ & $\begin{array}{c}\text { Protein } \\
\text { adsorption } \\
\text { Antioxidant }\end{array}$ & $\begin{array}{c}\text { Tissue } \\
\text { engineering }\end{array}$ & [48-50] \\
\hline & PLA-CL & $\begin{array}{l}\alpha \text {-toc, Silk } \\
\text { Fibroin (SF), } \\
\text { Curcumin } \\
\text { (C) }\end{array}$ & $\begin{array}{l}\text { Nanofiber } \\
\text { scaffold }\end{array}$ & $\begin{array}{c}\text { Preparation of a solution } \\
\text { with PLACL, SF, C, and } \\
\alpha \text {-Toc in HFIP. } \\
\text { Electrospinning of the } \\
\text { prepared solution. }\end{array}$ & $\begin{array}{l}\text { The scaffold induces } \\
\text { fibroblasts } \\
\text { proliferation and } \\
\text { attachment, and } \\
\text { stimulates collagen } \\
\text { secretion. }\end{array}$ & $\begin{array}{l}\text { Antioxidant and } \\
\text { anti- } \\
\text { inflammatory, } \\
\text { wound-healing } \\
\text { capacity }\end{array}$ & $\begin{array}{l}\text { Wound } \\
\text { treatment }\end{array}$ & [41] \\
\hline & $\begin{array}{l}\text { PLA and } \\
\text { PCL }\end{array}$ & $\begin{array}{c}\alpha \text {-toc } \\
\text { acetate }\end{array}$ & $\begin{array}{l}\text { Bilayer } \\
\text { nanofiber } \\
\text { scaffold }\end{array}$ & $\begin{array}{l}\text { Preparation of a solution } \\
\text { with PCL, PLA, and } \\
\text { Vitamin E in DCM. } \\
\text { Electrospinning of the } \\
\text { prepared solution. }\end{array}$ & $\begin{array}{l}\text { The scaffold induces } \\
\text { angiogenesis and cell } \\
\text { proliferation }\end{array}$ & $\begin{array}{l}\text { Antioxidant and } \\
\text { anti- } \\
\text { inflammatory, } \\
\text { wound-healing } \\
\text { capacity }\end{array}$ & $\begin{array}{l}\text { Wound } \\
\text { treatment }\end{array}$ & [42] \\
\hline & $\begin{array}{l}\mathrm{P}(3 \mathrm{HB}) / \\
\text { Bioglass }\end{array}$ & Vitamin E & $\begin{array}{l}\text { Foam } \\
\text { scaffold }\end{array}$ & $\begin{array}{l}\text { Incorporation of the } \\
\text { appropriate amounts of } \\
\text { vitamin E and MWCNTs } \\
\text { into the polymer solution. } \\
\text { Sonication of the mixture } \\
\text { before impregnating it } \\
\text { into the preforms. }\end{array}$ & $\begin{array}{l}\text { The scaffold has good } \\
\text { biocompatibility, } \\
\text { good protein } \\
\text { adsorption; } \\
\text { stimulates cell } \\
\text { proliferation and } \\
\text { allows } \\
\text { vascularization. }\end{array}$ & $\begin{array}{c}\text { Protein } \\
\text { adsorption } \\
\text { Antioxidant }\end{array}$ & $\begin{array}{l}\text { Bone tissue } \\
\text { engineering }\end{array}$ & [47] \\
\hline
\end{tabular}

\subsection{Vitamin E in Drug Delivery}

\subsubsection{Pharmaceutical Use of Vitamin E}

Nowadays, vitamin E has also gained particular importance due to its proven anticarcinogenic activities, which lead it to be an interesting candidate as an adjuvant anti- 
cancer treatment drug or as a preventive drug. In fact, its preventive properties were discovered according to research that showed that the Mediterranean diet, known to be rich in antioxidants such as vitamin $C$ and $E$, has a protective effect from certain cancers, such as colon cancer $[21,54]$. As the literature suggests, $\gamma$ - and $\delta$-tocopherol are more potent inducers of apoptosis than $\beta$ - and $\alpha$-tocopherols; in fact, despite its antioxidant power, it would seem that $\alpha$-tocopherol is not cytotoxic [55]. In particular, among all the various forms of vitamin $\mathrm{E}$, tocotrienols appear to have a stronger anti-proliferative and proapoptotic effect than tocopherols [56]. Due to its lipophilicity, vitamin E is able to cross the cell membrane but, given its insolubility in water, its bioavailability is limited. In fact, the biological mechanism of digestion of vitamin E occurs through emulsion into lipid droplets. The emulsion allows vitamin E to be transported (through micelles or vesicles) and thus to be absorbed by diffusion by the various target tissues [57,58]. For this reason, methods to encapsulate vitamin $\mathrm{E}$ for the use in drug delivery have been studied in the literature, using various materials such as synthetic polymers or biopolymers and different delivery systems: hydrogel, micro- and nano-particles, liposomes, and nano-emulsions.

In the literature, chitosan is widely explored as a drug delivery system to load alphatocopherol: the water solubility of chitosan is exploited to increase bioavailability of $\alpha$-tocopherol.

Majid Naghibzadeh et al. developed chitosan nanoparticles with alpha-tocopherol loaded by dispersing chitosan in water and dropping a solution of ethanol and $\alpha$-tocopherol. The nanoparticles are obtained by placing the mixtures in an ice bath and sonicated using the ultrasonic probe [59]. With a similar approach, J. Nam et al. created a chitosan-specific micelle for tocopherol and doxorubicin (DOX) delivery by grafting with a targeting ligand (anti-HER2/neu-polyethylene glycol [PEG] peptide). In this way, micelles have an anticancer effect, exploiting the synergistic effect between TP and DOX, and with site-specific drug delivery [60]. So, chitosan is a good biomaterial that can encapsulate tocopherol by $\mathrm{O} / \mathrm{W}$ emulsion either on its own or with the help of other polymers such as zein, an amphiphilic protein found in corn, which helps create a stronger polymeric complex with chitosan. In fact, Yangchao Luo et al. prepared and characterized nanoparticles by first preparing a solution in ethanol of zein and tocopherol and then, inserting into this another solution of chitosan and acetic acid [61].

In addition to chitosan, PCL was also investigated for drug delivery systems. Similar to that mentioned about chitosan, PCL nanoparticles loaded with tocopherol were made into $\mathrm{O} / \mathrm{W}$ emulsion with a successive ultrasonification method to optimize encapsulation. Youngjae Byun et al. formulate and characterize PCL nanoparticles loaded with tocopherol, using PCL dissolved in methylene chloride with tocopherol as an organic phase and PVA dissolved in PBS as an aqueous phase, with a subsequent ultrasonification in an ice bath [62]. Instead, Catherine Charcosset et al. created a PCL nanocapsule, using PCL dissolved in acetone with tocopherol as an organic phase and TWEEN 20 dissolved in water as an aqueous phase [63].

Another important biopolymer used in drug delivery is definitely hyaluronic acid, a hydrophilic compound, capable of forming a gel when immersed in water, which could be used also to enhance the water solubility of alpha-tocopherol. Parbeen Singh et al. created hyaluronic-acid-based $\beta$-cyclodextrin grafted copolymer to encapsulate vitamin E [64].

Moving on to another area, temperature-sensitive materials have received a great deal of attention in the drug delivery field, as they can optimize the encapsulation and controlled release of drugs. Cirley Quintero et al. used a PNIPAM-b-PCL-b-PNIPAM triblock copolymer as a thermosensitive material for nanoparticles. The obtained nanoparticles have a shell of the aforementioned polymer, loaded with $\alpha$-tocopherol. Their preparation is based on dissolution of $\alpha$-tocopherol and the corresponding copolymer in acetone, and a subsequent drop in an aqueous solution at pH 5 [65]. Likewise, Behrouz Mohammadi et al. have successfully nano-encapsulated vitamin E in stearic acid-lauric acid (SA-LA) in the form of a core-shell thermosensitive structure. The synthesis process involves always the 
$\mathrm{O} / \mathrm{W}$ emulsion with SA-LA and $\alpha$-tocopherol as an organic phase and PVA, PVP, Sodium SLS as an aqueous phase [66].

From what has been said so far, we can see that in the literature, typically vitamin $\mathrm{E}$ is encapsulated within different polymeric vectors (Table 3). There are also cases where $\alpha$ tocopherol is functionalized on metal nanoparticles such as gold to increase the scavenging ability of the latter for biological applications $[67,68]$.

Table 3. Polymeric vectors for Vitamin E encapsulation.

\begin{tabular}{cccc}
\hline Polymer & Molecule & Type of Vector & Ref. \\
\hline Chitosan & $\alpha$-toc & Nanoparticles & {$[59]$} \\
Chitosan & $\alpha$-toc and & Micelles & {$[60]$} \\
Zein & Doxorubicin & Nanoparticles & {$[61]$} \\
PCL & $\alpha$-toc & Nanoparticles & {$[62]$} \\
PCL & $\alpha$-toc & Nanocapsule & {$[63]$} \\
PNIPAM-b-PCL-b-PNIPAM & $\alpha$-toc & Injectable grafted copolymer & {$[64]$} \\
SA-LA & $\alpha$-toc & Nanoparticles & {$[65]$} \\
\hline
\end{tabular}

\subsubsection{Vitamin E as a Delivery System}

Most of the approved anti-cancer drugs, such as paclitaxel, docetaxel, etc., are lipophilic, which renders it challenging for their bioavailability and thus for their uptake by the target tissues [69].

Although tocopherols and tocotrienols have a nearly amphipathic structure, the hydrophilic part of the tocols, characterized by the hydroxyl group $(-\mathrm{OH})$, is too small to self-assemble spontaneously into a micellar structure. Conversion of the phenolic component of the vitamin to esters using acetic or succinic acid is often performed to expand the hydrophilic part and optimize the amphiphilic structure, thus creating more stable esterified compounds that can be easily used for drug delivery, such as $\alpha$-tocopheryl etherlinked acetic acid ( $\alpha$-TEA) or $\alpha$-tocopherol succinate ( $\alpha$-TOS), also discovered to be potent anti-cancer agents $[55,70,71]$. The esterification of $\alpha$-tocopherol succinate ( $\alpha$-TOS) with the important biomaterial, polyethylene glycol (PEG), forms a new compound, D-a-tocopheryl polyethylene glycol succinate (TPGS), widely used today in drug delivery as a non-ionic surfactant and micellar stabilizer, capable of forming micelles in water at a concentration as low as $0.02 \mathrm{wt} \%$. This new amphiphilic polymer has several advantages given by the physicochemical properties of PEG and vitamin E, such as high biocompatibility, improved cellular uptake of the drug, and anti-tumour activity, which allowed it to be approved by the FDA as a safe adjuvant [61-63]. TPGS is widely used as a surfactant and permeation enhancer (reviewed in [61]), as a prodrug carrier (reviewed in [72,73]), and also as a copolymer with other biopolymers such as PLA and PLGA or PCL (reviewed in [74,75]).

Another interesting synthetic polymer is formed by the esterification of alphatocopherol succinate with the glucidic polymer, inulin (INU), creating amphiphilic compounds obtained based on inulin with hydrolyzable groups, and with a vitamin E-based radical chain, called INVITE. This novel INU-based polymer easily self-assembles into nanocarriers; thus, it has been envisioned as a novel drug delivery system for the therapy of different diseases.

Delia Mandracchia et al. developed and characterized INVITE micelles, which have stability in water and a low size (about $50 \mathrm{~nm}$ ), and is used in different diseases for different targets. Due to the renal passive targeting ability of inulin, INVITE results as a good candidate for the drug delivery system for target tissues such as the urinary tract [76]. It has also been tested with good results for the delivery of celecoxib to the intestinal site against Caco-2 cells [77] conjugated with several other molecules such as biotin and succinic anhydride, creating INVITEBIO and INVITESA, respectively [78,79], and loaded with curcumin, creating INVITE C, for the treatment of diabetic retinopathy 
or neurodegenerative diseases $[80,81]$. Through the esterification of alpha-tocopherol succinate with hyaluronic acid, a novel amphiphilic compound was created for the tumourtargeted delivery system, exploiting the ability of hyaluronic acid to bind to the membrane receptor CD44, a protein overexpressed by tumour cells. The created polymer name is HA-VES and was used by Jinling Wang et al. for the release of anti-cancer agent Doxorubicin [82].

That said, as can be seen from Figure 5, vitamin E is often bound with other biomolecules able to make the molecule more hydrophilic.
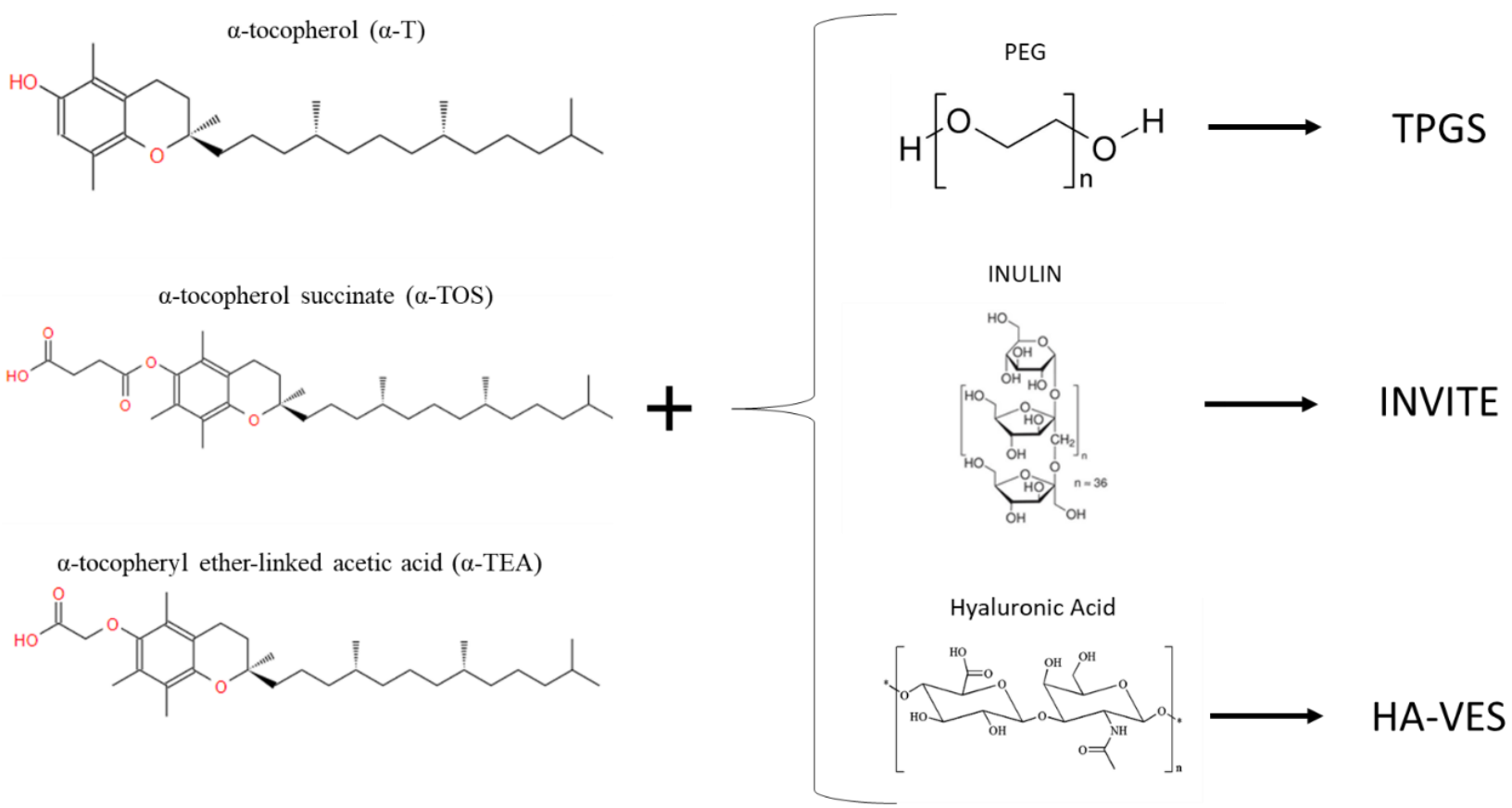

Figure 5. Chemical structure of different forms of vitamin E used for drug delivery system.

This creates amphiphilic compounds that are able to reorganize themselves into systems suitable for drug delivery. In contrast, Khushwinder kaur et al. have succeeded in creating nanoparticles of pure $\alpha$-tocopherol. The work suggests a method that involves an emulsion of the components with a water:surfactant:oil ratio where the organic phase consists of the first surfactant TWEEN 80 and tocopherol in ethanol, and the aqueous phase is water containing the second surfactant SSL. Through this method, they were able to create stable nanoparticles for the encapsulation of curcumin as an antioxidant and benzylisothiocyanate as an anti-cancer agent [83].

\section{Methods to Detect and Quantify Vitamin E within Materials}

Vitamin E can be easily detected in different liquid media, such as in oils, serum, human milk, foods, etc., by different methods including HPLC, FTIR, RAMAN, UV-VIS, and spectrophotometric methods. Recently, some protocols were also developed for the analysis of vitamin $\mathrm{E}$ incorporated into cosmetics and food packaging and contained in food [84-89].

The first method usually used to allow a simple and rapid quantitative determination of $\alpha$-tocopherol is High-Performance Liquid Chromatography (HPLC). In fact, HPLC is one of the most powerful tools for the determination of fat-soluble vitamins and has been widely used for their separation and detection; different detectors can be used for vitamins such as UV-VIS, fluorescence, and mass spectrometry. In the case of vitamin E, typically the HPLC column is connected to an UV absorbance detector as the compound absorbs the ultraviolet light, particularly around $290 \mathrm{~nm}$. This method is, in fact, used not only to analyse quantitatively the content of alpha-tocopherol in food or beverages, 
but also in cosmetics and in biological samples including human plasma and human milk [86,89-92]. Another way to detect and quantify $\alpha$-tocopherol is the Fourier Transform Infrared Spectroscopy (FTIR). Sandra et al. developed a quick procedure for the quantitative analysis of $\alpha$-tocopherol in vegetable oils as an alternative to HPLC methods, using FTIRATR methodology. By analysing 13 vegetable oils, with a known content of vitamin E, a research team created a calibration curve which was then used to measure the alphatocopherol content of the vegetable oil concerned quantitatively [93].

For qualitative measurements, FTIR was also used for detecting the functional groups of a hydrophobic film of vitamin E deposited on a copper substrate [94]. Thanks to its clear absorbance peak at $290 \mathrm{~nm}$, visible ultraviolet spectroscopy (UV-Vis) proved to be able to detect the presence of vitamin E even at low concentrations $[95,96]$.

Along with FTIR, RAMAN is a potential alternative method to have qualitative detection of the molecule. It is used to detect vitamin $\mathrm{E}$ in oil water emulsions and in biological samples [97,98]. Surface-enhanced Raman spectroscopy (SERS) technology is of a high level of interest: it exploits the amplification of Raman diffusion by molecules adsorbed on a metal or on metallic nanoparticles $[99,100]$. Typically, most SERS techniques use metal aqueous colloids as a substrate, which require that compounds to be analysed must be water soluble. For water insoluble analytes, such as vitamin E, the matter is more complicated. Given the disadvantage of using colloidal Ag nanoparticles to measure SERS of the analyte directly, Tiantian Cai et al. have successfully tried other methods to analyse vitamin E: after dissolving the compound in chloroform, the solution obtained is dripped onto the surface of a metal substrate with surface Raman activity. Another method could be to immerse the metal substrate in the sample solution containing vitamin E directly, to extract it after a certain time, and to measure it at RAMAN after the solvent has evaporated [101].

Thanks to its antioxidant properties, vitamin E can also be analysed and quantified through all those methods that exploit chemical reactions, typically redox, to develop coloured compounds that are then measured spectrophotometrically. In general, spectrophotometric methods for vitamin E determination use oxidation of the aromatic ring of $\alpha$-tocopherol, creating tocopherylquinone, by oxidizing agents that ultimately yield products with spectrophotometric staining. Among these methods, there is definitely the DPPH method, which uses a free radical of purple colour, which discolours when it reacts with vitamin E. Valeria M. et al. have used the DPPH method to compare the antioxidant power of drugs containing alpha-tocopherol. The problem of the DPPH method is its low reproducibility due to the low stability of the radical [102].

Another such methodology is the Folin-Ciocâlteu (FC) reagent in an aqueous solution. In this case, however, given the insolubility of vitamin $\mathrm{E}$ in water, this methodology is not the optimal one. However, modifications have been made to the FC method to enable the measurement of lipophilic and hydrophilic antioxidants concentrations simultaneously [103].

Albeit less used and dated, there are many other methods using different oxidizing reagents such as $\mathrm{Fe}$ (III)-bathophenanthroline, $\mathrm{Cu}$ (II)-neocuproine, or silver nitrate, but they require a rigid control of the conditions for precise results [104]. Another method is the Emmerie and Engel colour reaction with ferric chloride: it is a precise and easy-to-perform reaction, and therefore the approach of choice for a routine clinical laboratory [105]. Based on this work, more recently, Jameel G. Jargar et al. took advantage of different reagents such as 2,2'-bipyridyl, ferric chloride, and xylene to perform the colour reaction [106].

Finally, although a very old and no longer used method, nitric acid combined with ethanol was used to oxidise $\alpha$-tocopherol, forming the coloured red o-quinone which can be detected spectrophotometrically (Figure 6) [107]. 


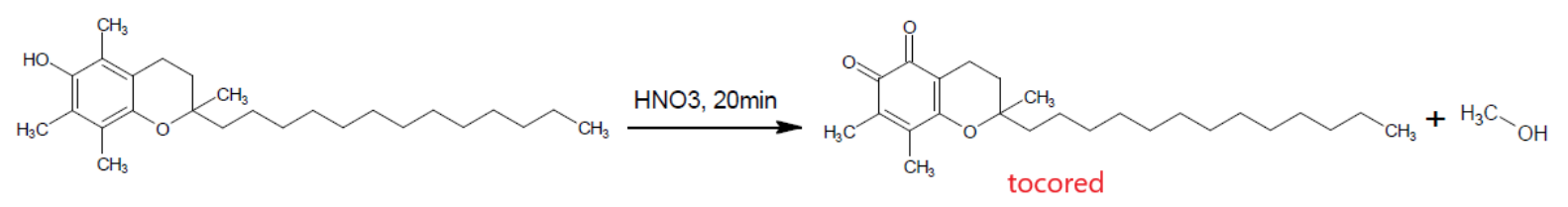

Figure 6. Formation of Tocored with Nitric Acid.

Thanks to the vitamin $\mathrm{E}$ detection methods employed in various applications involving cosmetics, food packaging, and so on, it is possible to apply the above methods to the biomedical field for the detection of vitamin $\mathrm{E}$ when combined with different biomaterials.

Certainly, it is easy to find detection methods in the literature when vitamin E is combined with UHWMPE, as it is the most widely applied biomaterial coupled with vitamin E today.

For quantification methods, with HPLC analysis, it is convenient to quantify the vitamin $\mathrm{E}$ content within UHMWPE using a calibration curve produced from the areas of the HPLC peaks [108]. Instead, Hufen Julia et al. developed an accurate method to detect $\alpha$-tocopherol content in UHWMPE using HPLC analysis to separate it and determine its concentration by UV-Vis spectroscopy with a corresponding calibration curve [109]. However, it is also possible to use only UV-VIS in absorbance mode combined with FTIR to quantify vitamin E within UHMWPE [110]. Vitamin E blended with polyethylene induces yellowing of the sample; Martínez-Morlanes et al. exploited this characteristic using the colorimetric technique and reflectance spectroscopy to detect vitamin $\mathrm{E}$ embedded in polyethylene samples quantitatively [111]. These types of methods, especially HPLC, are also used in drug delivery to calculate the drug encapsulation efficiency, resulting in the quantification of the vitamin E encapsulated within polymeric nanoparticles [62,64,65]. With the same object, in tissue engineering, HPLC is used to quantify vitamin E content inside the matrices or scaffolds $[44,112]$.

For qualitative methods, since vitamin $\mathrm{E}$ is an extremely hydrophobic molecule, another important way to detect the presence of tocopherol on different substrates is definitely the measurement of the contact angle, the quickest test to evaluate a surface modification [113]. Filippo Renò et al. used the contact angle measurement on PLA blended with Vitamin E, and they discovered that the blend enriched with vitamin E was more easily wetted $[48,49]$.

To get a more in-depth understanding of the chemical bonds between the substrate and the deposited molecule, the XPS technique is useful, as in the case of Elena Stoleru et al. who used XPS to have information about the stability of the chitosan/vitamin E coating deposited on a polyethylene substrate [113].

Once the characteristic peaks of vitamin E are known, the FTIR analysis is helpful, not only to detect vitamin E [42], but also to analyse the eventual shifts in wavenumber of the peaks that denote an interaction between tocopherol and the combined biomaterials. Ahmad Salawi et al. used the FTIR technique to analyse the interaction between a new copolymer called Soluplus and $\alpha$-tocopherol for a wound-healing application [114], and Joana T. Martins et al. studied the physiochemical effect of the incorporation of $\alpha$-tocopherol in chitosan-based films through a different analysis including FTIR [115].

In the biomedical field, the DPPH test is used to analyse the radical scavenging ability of vitamin E combined with biomaterials, as Elena Stoleru et al. did on a film electrosprayed with a chitosan/vitamin E formulation [113]. DPPH was used also by Zhou Nier et al. to test the antioxidant activity of Au nanoparticles functionalized with Trolox (hydrophilic analogue of alpha-tocopherol) $[67,68]$. The table (Table 4) reports the characterization methods used to detect vitamin $\mathrm{E}$ when combined with different biomaterials. 
Table 4. Method of Vitamin E detection when it is combined with biomaterials.

\begin{tabular}{|c|c|c|c|c|c|}
\hline Technique & Combined Material & Molecule Detected & Method & Information & Ref. \\
\hline \multirow{6}{*}{ HPLC } & UHWMPE & $\alpha$-tocopherol & $\begin{array}{l}\text { HPLC connected to UV/Vis diode array } \\
\text { detector at } 297 \mathrm{~nm} \text {, construction of } \\
\text { calibration curve of HPLC peak area. }\end{array}$ & Quantitative & [108] \\
\hline & UHWMPE & $\alpha$-tocopherol & $\begin{array}{l}\text { HPLC connected to UV/Vis diode array } \\
\text { detector, construction of calibration curve } \\
\text { of absorbance peak area at } 290 \mathrm{~nm}\end{array}$ & Quantitative & [109] \\
\hline & Collagen mesh & $\alpha$-tocopherol & $\begin{array}{l}\text { HPLC connected to a fluorescence detector, } \\
\text { detection at excitation wavelength of } 290 \\
\mathrm{~nm} \text { and emission wavelength of } 330 \mathrm{~nm}\end{array}$ & Quantitative & [112] \\
\hline & $\begin{array}{l}\text { Alginate and hyaluronate } \\
\text { film }\end{array}$ & $\alpha$-tocopherol acetate & $\begin{array}{l}\text { HPLC connected to UV/Vis diode array } \\
\text { detector, construction of calibration curve } \\
\text { of absorbance peak area at } 285 \mathrm{~nm}\end{array}$ & Quantitative & [44] \\
\hline & $\begin{array}{l}\text { Hyaluronic-acid-based } \\
\beta \text {-cyclodextrin copolymer }\end{array}$ & $\alpha$-tocopherol & $\begin{array}{l}\text { HPLC connected to UV/Vis diode array } \\
\text { detector }\end{array}$ & Quantitative & [64] \\
\hline & $\begin{array}{l}\text { PNIPAM-b-PCL-b-PNIPAM } \\
\text { copolymer }\end{array}$ & $\alpha$-tocopherol & $\begin{array}{l}\text { HPLC equipped with a differential } \\
\text { refraction index detector }\end{array}$ & Quantitative & [65] \\
\hline \multirow{4}{*}{ UV-VIS } & UHWMPE & $\alpha$-tocopherol & $\begin{array}{l}\text { Construction of calibration curve of } \\
\text { absorbance peak area at } 290 \mathrm{~nm}\end{array}$ & Quantitative & [110] \\
\hline & UHWMPE & $\alpha$-tocopherol & $\begin{array}{l}\text { Analysis of reflectance spectra which } \\
\text { presents a minimum around } 290 \mathrm{~nm} \text { and a } \\
\text { decrease of reflectance at } 400-500 \mathrm{~nm} \text {. }\end{array}$ & Detection & [111] \\
\hline & Hyaluronic acid & $\begin{array}{l}\alpha \text {-tocopherol } \\
\text { succinate }\end{array}$ & $\begin{array}{l}\text { Construction of calibration curve of } \\
\text { absorbance peak area at } 285 \mathrm{~nm}\end{array}$ & Quantitative & [116] \\
\hline & $\mathrm{PLA}+\mathrm{PCL}$ & $\alpha$-tocopherol acetate & $\begin{array}{l}\text { Construction of calibration curve of } \\
\text { absorbance peak area at } 284 \mathrm{~nm}\end{array}$ & Quantitative & [42] \\
\hline $\begin{array}{l}\text { Colorimetric } \\
\text { Assay }\end{array}$ & UHWMPE & $\alpha$-tocopherol & $\begin{array}{c}\text { The yellowing of the sample was analysed } \\
\text { through three parameters }(\mathrm{a}, \mathrm{b}, \mathrm{L}) \text { of } \\
\text { CIELAB colour space, and a calibration } \\
\text { curve of colour distances was constructed. }\end{array}$ & Quantitative & [111] \\
\hline \multirow[t]{2}{*}{ FTIR-ATR } & UHWMPE & $\alpha$-tocopherol & $\begin{array}{l}\text { Analysis of peaks. } \\
\text { For quantitative analysis, calibration curve } \\
\text { of these peaks is needed. }\end{array}$ & $\begin{array}{l}\text { Analysis of Vitamin E } \\
\text { transformation products in } \\
\text { polymer samples prior to } \\
\text { extraction and quantitative. }\end{array}$ & [108] \\
\hline & Collagen & $\alpha$-tocopherol & Analysis of main peaks & Characterization of film & [45] \\
\hline \multirow{6}{*}{ FTIR-ATR } & Magnetite & $\begin{array}{l}\alpha \text {-tocopheryl } \\
\text { succinate }\end{array}$ & Analysis of main peaks & $\begin{array}{c}\text { Characterization of chemical } \\
\text { modification of } \\
\text { nanoparticles }\end{array}$ & [71] \\
\hline & Chitosan & $\alpha$-tocopherol & Analysis of peaks & $\begin{array}{l}\text { Physical bonds and chemical } \\
\text { interactions are reflected by } \\
\text { changes in characteristic } \\
\text { spectral peaks. }\end{array}$ & [115] \\
\hline & Chitosan & $\alpha$-tocopherol & Analysis of peaks & $\begin{array}{l}\text { Characterization of } \\
\text { nanoparticles }\end{array}$ & [59] \\
\hline & PCL/PLA & $\alpha$-tocopherol acetate & Analysis of peaks & $\begin{array}{c}\text { Characterization of } \\
\text { membranes }\end{array}$ & [42] \\
\hline & Soluplus & $\alpha$-tocopherol & Analysis of peaks & $\begin{array}{c}\text { Analysis of bonding } \\
\text { between Soluplus/vitamin E }\end{array}$ & [114] \\
\hline & Polyethylene & $\alpha$-tocopherol & Analysis of peaks from $600-4000 \mathrm{~cm}^{-1}$ & $\begin{array}{l}\text { Analysis of interaction } \\
\text { between vitamin E and } \\
\text { chitosan }\end{array}$ & [113] \\
\hline XPS & Polyethylene & $\alpha$-tocopherol & $\begin{array}{l}\text { All binding energies were referenced to the } \\
\text { C1s peak at } 285 \mathrm{eV} \text {. }\end{array}$ & $\begin{array}{l}\text { Analysis of covalent } \\
\text { bonding }\end{array}$ & [113] \\
\hline \multirow{3}{*}{ DPPH } & Polyethylene & $\alpha$-tocopherol & $\begin{array}{l}\text { The scavenging activity was estimated } \\
\text { RSA }(\%)= \\
(1-(\text { A sample/Acontrol })) \times 100 \\
\text { measuring the adsorption at } 515 \mathrm{~nm} \text { after } \\
\quad 30 \text { min in dark condition. }\end{array}$ & $\begin{array}{l}\text { Radical scavenging activity } \\
\text { evaluation }\end{array}$ & [113] \\
\hline & Chitosan & $\alpha$-tocopherol & $\begin{array}{l}\text { The scavenging activity was estimated } \\
\text { RSA }(\%)= \\
(1-(\text { A sample } / \text { Acontrol })) \times 100 \\
\text { measuring the adsorption at } 517 \mathrm{~nm} \text { after } \\
\quad 30 \text { min in dark condition. }\end{array}$ & $\begin{array}{l}\text { Radical scavenging activity } \\
\text { evaluation }\end{array}$ & [115] \\
\hline & Collagen/chitosan & $\alpha$-tocopherol & $\begin{array}{l}\text { DPPH were measured by the adsorption at } \\
517 \mathrm{~nm} \text { after } 30 \mathrm{~min} \text { in dark condition. } \\
\text { DPPH loss which is a concentration of } \\
\text { DPPH radicals reacted with antioxidants. }\end{array}$ & Antioxidant activity & [112] \\
\hline
\end{tabular}


Table 4. Cont.

\begin{tabular}{|c|c|c|c|c|c|}
\hline Technique & Combined Material & Molecule Detected & Method & Information & Ref. \\
\hline \multirow[t]{2}{*}{$\begin{array}{l}\text { Contact } \\
\text { Angle }\end{array}$} & Polyethylene & $\alpha$-tocopherol & $\begin{array}{l}\text { Contact angle titrations were performed by } \\
\text { measuring sets of contact angles at each } \\
\text { pH value. }\end{array}$ & $\begin{array}{l}\text { Analysis of hydrophobic } \\
\text { behaviour as pH increases }\end{array}$ & [106] \\
\hline & PLA & $\alpha$-tocopherol & Static contact angle & $\begin{array}{l}\text { Analysis of material } \\
\text { wettability change }\end{array}$ & {$[48,49]$} \\
\hline
\end{tabular}

\section{Conclusions}

This review is intended to give a general overview over the past 20 years of the biomedical use of vitamin $\mathrm{E}$ in all its forms. It sets out to recall its biological role, tracing the fundamental motives of why the molecule has become a widely discussed object in scientific research. Vitamin $\mathrm{E}$ has a number of relevant biological actions (antioxidant properties, anti-inflammatory properties, inhibition of platelet aggregation, preservation of integrity of the cell membrane) with a positive outcome on immune system, bone health, protection of the skin, age-related diseases, and cancer.

Apart from dietary supplements or food additives, several biomedical products on the market include vitamin E and exploit its benefits (wound healing, UHMWPE inserts); other current commercial applications are in cosmetics and food packaging. Some new fields of application are investigated in the area of biomaterials at the research stage and are of a great potential impact in the future; in this respect, we can mention coatings of bone implants, drug delivery systems, and tissue (both hard and soft) regeneration.

Anti-microbial action of vitamin $\mathrm{E}$ and its derivate compounds is still under discussion.

In the perspective of the future, further research must be carried out to understand the controversial antibacterial activity of vitamin E better, in order to be able to give new properties to other biomedical materials, in addition to those already discussed. New types of combinations with biomaterials still need to be studied and optimized, such as the grafting of the molecule on metal surfaces through coating or functionalization.

Author Contributions: F.G. wrote the first draft and participated the revision; S.S. participated in the drafting and revised its final version. Both authors have read and agreed to the published version of the manuscript.

Funding: This research received no external funding.

Institutional Review Board Statement: Not applicable.

Informed Consent Statement: Not applicable.

Data Availability Statement: Not applicable.

Conflicts of Interest: The authors declare no conflict of interest.

\section{References}

1. Rizvi, S.; Raza, S.T.; Ahmed, F.; Ahmad, A.; Abbas, S.; Mahdi, F. The role of Vitamin E in human health and some diseases. Sultan Qaboos Univ. Med. J. 2014, 14, 157-165.

2. Mutalip, S.S.M.; Ab-Rahim, S.; Rajikin, M.H. Vitamin E as an antioxidant in female reproductive health. Antioxidants 2018, 7, 22. [CrossRef]

3. Colombo, M.L. An update on vitamin E, tocopherol and tocotrienol-perspectives. Molecules 2010, 15, 2103-2113. [CrossRef] [PubMed]

4. Jiang, Q. Natural forms of vitamin E: Metabolism, antioxidant, and anti-inflammatory activities and their role in disease prevention and therapy. Free Radic. Biol. Med. 2014, 72, 76-90. [CrossRef] [PubMed]

5. Wang, X.; Quinn, P.J. Vitamin E and its function in membranes. Prog. Lipid Res. 1999, 38, 309-336. [CrossRef]

6. Engin, K.N. Alpha-tocopherol: Looking beyond an antioxidant. Mol. Vis. 2009, 15, 855-860. [PubMed]

7. Wang, X.; Quinn, P.J. The location and function of vitamin E in membranes (Review). Mol. Membr. Biol. 2000, 17, 143-156. [CrossRef] [PubMed]

8. Gilgun-Sherki, Y.; Melamed, E.; Offen, D. Oxidative stress induced-neurodegenerative diseases: The need for antioxidants that penetrate the blood brain barrier. Neuropharmacology 2001, 40, 959-975. [CrossRef] 
9. Lloret, A.; Esteve, D.; Monllor, P.; Cervera-Ferri, A.; Lloret, A. The effectiveness of vitamin E treatment in alzheimer's disease. Int. J. Mol. Sci. 2019, 20, 879. [CrossRef]

10. Schubert, M.; Kluge, S.; Schmölz, L.; Wallert, M.; Galli, F.; Birringer, M.; Lorkowski, S. Long-chain metabolites of vitamin E: Metabolic activation as a general concept for lipid-soluble vitamins? Antioxidants 2018, 7, 10. [CrossRef]

11. Reitera, E.; Jiang, Q.; Christen, S. Anti-inflammatory properties of $\alpha$ - and $\gamma$-tocopherol. Bone 2007, 28, 668-691. [CrossRef] [PubMed]

12. Wu, D.; Hayek, M.G.; Meydani, S.N. Symposium: Molecular mechanisms of protective effects of vitamin E in atherosclerosis: Vitamin E and macrophage cyclooxygenase regulation in the aged. J. Nutr. 2001, 131, 382-388. [CrossRef] [PubMed]

13. Lee, G.Y.; Han, S.N. The role of vitamin E in immunity. Nutrients 2018, 10, 1614. [CrossRef]

14. Hardbower, D.M.; de Sablet, T.; Chaturvedi, R.; Wilson, K.T. Chronic inflammation and oxidative stress: The smoking gun for helicobacter pylori-induced gastric cancer? Gut Microbes 2013, 4, 475-481. [CrossRef] [PubMed]

15. Traber, M.G.; Atkinson, J. Vitamin E, antioxidant and nothing more. Free Radic. Biol. Med. 2007, 43, 4-15. [CrossRef] [PubMed]

16. Keen, M.; Hassan, I. Vitamin E in dermatology. Indian Dermatol. Online J. 2016, 7, 311. [CrossRef] [PubMed]

17. Nazrun, A.S.; Norazlina, M.; Norliza, M.; Nirwana, S.I. The anti-inflammatory role of vitamin e in prevention of osteoporosis Adv. Pharmacol. Sci. 2012, 2012, 142702. [CrossRef]

18. Wong, S.K.; Mohamad, N.V.; Ibrahim, N.; Chin, K.Y.; Shuid, A.N.; Ima-Nirwana, S. The molecular mechanism of Vitamin E as a bone-protecting agent: A review on current evidence. Int. J. Mol. Sci. 2019, 20, 1453. [CrossRef]

19. Rossato, M.F.; Hoffmeister, C.; Tonello, R.; Ferreira, A.P.d.; Ferreira, J. Anti-inflammatory Effects of Vitamin E on Adjuvant-Induced Arthritis in Rats. Inflammation 2015, 38, 606-615. [CrossRef]

20. Feresin, R.G.; Johnson, S.A.; Elam, M.L.; Kim, J.S.; Khalil, D.A.; Lucas, E.A.; Smith, B.J.; Payton, M.E.; Akhter, M.P.; Arjmandi, B.H. Effects of Vitamin e on Bone Biomechanical and Histomorphometric Parameters in Ovariectomized Rats. J. Osteoporos. 2013, 2013, 825985. [CrossRef]

21. Constantinou, C.; Papas, A.; Constantinou, A.I. Vitamin E and cancer: An insight into the anticancer activities of vitamin E isomers and analogs. Int. J. Cancer 2008, 123, 739-752. [CrossRef] [PubMed]

22. Capuron, L.; Moranis, A.; Combe, N.; Cousson-Gélie, F.; Fuchs, D.; De Smedt-Peyrusse, V.; Barberger-Gateau, P.; Layé, S. Vitamin E status and quality of life in the elderly: Influence of inflammatory processes. Br. J. Nutr. 2009, 102, 1390-1394. [CrossRef]

23. Tintino, S.R.; Morais-Tintino, C.D.; Campina, F.F.; Pereira, R.L.; Costa, M.; Braga, M.F.B.M.; Limaverde, P.W.; Andrade, J.C.; Siqueira-Junior, J.P.; Coutinho, H.D.M.; et al. Action of cholecalciferol and alpha-tocopherol on Staphylococcus aureus efflux pumps. EXCLI J. 2016, 15, 315-322. [PubMed]

24. Abd, D.; Kader, A.; Aziz, F.M. Antibacterial Effects of Vitamin E: In Vitro Study. J. Biotechnol. Res. Cent. $2013,7,17-23$.

25. Naguib, M.M.; Valvano, M.A. Vitamin E Increases Antimicrobial Sensitivity by Inhibiting Bacterial Lipocalin Antibiotic Binding. mSphere 2018, 3, e00564-18. [CrossRef]

26. Andrade, J.C.; Morais-Braga, M.F.; Guedes, G.M.; Tintino, S.R.; Freitas, M.A.; Menezes, I.R.; Coutinho, H.D. Enhancement of the antibiotic activity of aminoglycosides by alpha-tocopherol and other cholesterol derivates. Biomed. Pharmacother. 2014, 68, 1065-1069. [CrossRef]

27. Vergalito, F.; Pietrangelo, L.; Petronio Petronio, G.; Colitto, F.; Alfio Cutuli, M.; Magnifico, I.; Venditti, N.; Guerra, G.; Di Marco, R. Vitamin E for prevention of biofilm-caused Healthcare-associated infections. Open Med. 2020, 15, 14-21. [CrossRef] [PubMed]

28. Williams, D.L.; Vinciguerra, J.; Lerdahl, J.M.; Bloebaum, R.D. Does Vitamin E-blended UHMWPE Prevent Biofilm Formation? Clin. Orthop. Relat. Res. 2015, 473, 928-935. [CrossRef]

29. Bracco, P.; Oral, E. Vitamin E-stabilized UHMWPE for total joint implants: A review. Clin. Orthop. Relat. Res. 2011, 469, 2286-2293. [CrossRef]

30. Kurtz, S.M.; Bracco, P.; Costa, L.; Oral, E.; Muratoglu, O.K. 17 Vitamin E-Blended UHMWPE Biomaterials, 3rd ed.; Elsevier Inc.: Amsterdam, The Netherlands, 2002.

31. Wolf, C.; Krivec, T.; Blassnig, J.; Lederer, K.; Schneider, W. Examination of the suitability of $\alpha$-tocopherol as a stabilizer for ultra-high molecular weight polyethylene used for articulating surfaces in joint endoprostheses. J. Mater. Sci. Mater. Med. 2002, 13, 185-189. [CrossRef]

32. Takahashi, Y.; Yamamoto, K.; Pezzotti, G. Effects of vitamin e blending on plastic deformation mechanisms of highly crosslinked ultrahigh molecular weight polyethylene (HXL-UHMWPE) in total hip arthroplasty. Acta Biomater. 2015, 15, 227-236. [CrossRef] [PubMed]

33. Oral, E.; Muratoglu, O.K. Vitamin E diffused, highly crosslinked UHMWPE: A review. Int. Orthop. 2011, 35, 215-223. [CrossRef] [PubMed]

34. Bidossi, A.; Bortolin, M.; Toscano, M.; De Vecchi, E.; Romanò, C.L.; Mattina, R.; Drago, L. In vitro comparison between $\alpha$ tocopheryl acetate and $\alpha$-tocopheryl phosphate against bacteria responsible of prosthetic and joint infections. PLoS ONE 2017, 12, e0182323. [CrossRef]

35. Satué, M.; Ramis, J.M.; Monjo, M. Cholecalciferol synthesized after UV-activation of 7-dehydrocholesterol onto titanium implants inhibits osteoclastogenesis in vitro. J. Biomed. Mater. Res. Part A 2015, 103, 2280-2288. [CrossRef] [PubMed] 
36. Satué, M.; Monjo, M.; Ronold, H.J.; Lyngstadaas, S.P.; Ramis, J.M. Titanium implants coated with UV-irradiated vitamin D precursor and vitamin E: In vivo performance and coating stability. Clin. Oral Implant. Res. 2017, 28, 424-431. [CrossRef] [PubMed]

37. Lovati, A.B.; Bottagisio, M.; Maraldi, S.; Violatto, M.B.; Bortolin, M.; De Vecchi, E.; Bigini, P.; Drago, L.; Romano, C.L. Vitamin E phosphate coating stimulates bone deposition in implant-related infections in a rat model. Clin. Orthop. Relat. Res. 2018, 476, 1324-1338. [CrossRef]

38. Wang, P.H.; Huang, B.S.; Horng, H.C.; Yeh, C.C.; Chen, Y.J. Wound healing. J. Chin. Med. Assoc. 2018, 81, 94-101. [CrossRef]

39. Kanikireddy, V.; Varaprasad, K.; Jayaramudu, T.; Karthikeyan, C.; Sadiku, R. Carboxymethyl cellulose-based materials for infection control and wound healing: A review. Int. J. Biol. Macromol. 2020, 164, 963-975. [CrossRef]

40. Ehterami, A.; Salehi, M.; Farzamfar, S.; Samadian, H.; Vaez, A.; Ghorbani, S.; Ai, J.; Sahrapeyma, H. Chitosan/alginate hydrogels containing Alpha-tocopherol for wound healing in rat model. J. Drug Deliv. Sci. Technol. 2019, 51, 204-213. [CrossRef]

41. Gandhimathi, C.; Venugopal, J.R.; Bhaarathy, V.; Ramakrishna, S.; Kumar, S.D. Biocomposite nanofibrous strategies for the controlled release of biomolecules for skin tissue regeneration. Int. J. Nanomed. 2014, 9, 4709-4722. [CrossRef]

42. Zahid, S.; Khalid, H.; Ikram, F.; Iqbal, H.; Samie, M.; Shahzadi, L.; Shah, A.T.; Yar, M.; Chaudhry, A.A.; Awan, S.J.; et al. Bi-layered $\alpha$-tocopherol acetate loaded membranes for potential wound healing and skin regeneration. Mater. Sci. Eng. C 2019, 101, 438-447. [CrossRef] [PubMed]

43. Taepaiboon, P.; Rungsardthong, U.; Supaphol, P. Vitamin-loaded electrospun cellulose acetate nanofiber mats as transdermal and dermal therapeutic agents of vitamin A acid and vitamin E. Eur. J. Pharm. Biopharm. 2007, 67, 387-397. [CrossRef]

44. Pereira, G.G.; Guterres, S.S.; Balducci, A.G.; Colombo, P.; Sonvico, F. Polymeric films loaded with vitamin e and aloe vera for topical application in the treatment of burn wounds. BioMed Res. Int. 2014, 2014, 641590. [CrossRef]

45. Trombino, S.; Cassano, R.; Ferrarelli, T.; Isacchi, B.; Bilia, A.R.; Picci, N. Collagen $\alpha$-tocopherulate for topical applications: Preparation, characterization, and antioxidant activity evaluation. Macromol. Res. 2012, 20, 939-943. [CrossRef]

46. Krafts, K. Tissue Repair. In Encyclopedia of Toxicology, 3rd ed.; Elsevier: Amsterdam, The Netherlands, 2014; pp. 577-583. [CrossRef]

47. Misra, S.K.; Ansari, T.I.; Valappil, S.P.; Mohn, D.; Philip, S.E.; Stark, W.J.; Roy, I.; Knowles, J.C.; Salih, V.; Boccaccini, A.R. Poly(3-hydroxybutyrate) multifunctional composite scaffolds for tissue engineering applications. Biomaterials 2010, 31, $2806-2815$. [CrossRef] [PubMed]

48. Aina, V.; Gatti, S.; Cannas, M.; Reno, F. Effect of vitamin E addition to poly (D,L) -lactic acid on surface properties and osteoblast behaviour. Biomaterials 2005, 26, 5594-5599. [CrossRef]

49. Paul, G.; Rizzi, M.; Gatti, G.; Marchese, L.; Ren, F. Poly (D,L) Lactic Acid Blending with Vitamin E Increases Polymer Hemocompatibility: An Hydrophilic Effect. J. Appl. Polym. Sci. 2013, 129, 1527-1533. [CrossRef]

50. Campoccia, D.; Visai, L.; Renò, F.; Cangini, I.; Rizzi, M.; Poggi, A.; Montanaro, L.; Rimondini, L.; Arciola, C.R. Bacterial adhesion to poly-(D,L)lactic acid blended with vitamin E: Toward gentle anti-infective biomaterials. J. Biomed. Mater. Res. Part A 2015, 103, 1447-1458. [CrossRef] [PubMed]

51. Antoniac, I.; Popescu, D.; Zapciu, A.; Antoniac, A.; Miculescu, F.; Moldovan, H. Magnesium filled polylactic acid (PLA) material for filament based 3D printing. Materials 2019, 12, 719. [CrossRef]

52. Mahdieh, Z.; Bagheri, R.; Eslami, M.; Amiri, M.; Shokrgozar, M.A.; Mehrjoo, M. Thermoplastic starch/ethylene vinyl alcohol/forsterite nanocomposite as a candidate material for bone tissue engineering. Mater. Sci. Eng. C 2016, 69, 301-310. [CrossRef]

53. Qu, Y.; Tang, J.; Liu, L.; Song, L.L.; Chen, S.; Gao, Y. $\alpha$-Tocopherol liposome loaded chitosan hydrogel to suppress oxidative stress injury in cardiomyocytes. Int. J. Biol. Macromol. 2019, 125, 1192-1202. [CrossRef]

54. Grosso, G.; Buscemi, S.; Galvano, F.; Mistretta, A.; Marventano, S.; La Vela, V.; Drago, F.; Gangi, S.; Basile, F.; Biondi, A. Mediterranean diet and cancer: Epidemiological evidence and mechanism of selected aspects. BMC Surg. 2013, 13, S14. [CrossRef] [PubMed]

55. Neophytou, C.M.; Constantinou, A.I. Drug delivery innovations for enhancing the anticancer potential of vitamin e isoforms and their derivatives. BioMed Res. Int. 2015, 2015, 584862. [CrossRef] [PubMed]

56. Aggarwal, B.B.; Sundaram, C.; Prasad, S.; Kannappan, R. Tocotrienols, the vitamin E of the 21st century: Its potential against cancer and other chronic diseases. Biochem. Pharmacol. 2010, 80, 1613-1631. [CrossRef] [PubMed]

57. Borel, P.; Preveraud, D.; Desmarchelier, C. Bioavailability of vitamin E in humans: An update. Nutr. Rev. 2013, 71, 319-331. [CrossRef] [PubMed]

58. Reboul, E. Vitamin e bioavailability: Mechanisms of intestinal absorption in the spotlight. Antioxidants 2017, 6, 95. [CrossRef] [PubMed]

59. Faramarzi, M.A.; Naghibzadeh, M.; Amani, A.; Amini, M.; Esmaeilzadeh, E.; Mottaghi-Dastjerdi, N. An insight into the interactions between-tocopherol and chitosan in ultrasound-prepared nanoparticles. J. Nanomater. 2010, 2010, 818717. [CrossRef]

60. Nam, J.P.; Lee, K.J.; Choi, J.W.; Yun, C.O.; Nah, J.W. Targeting delivery of tocopherol and doxorubicin grafted-chitosan polymeric micelles for cancer therapy: In vitro and in vivo evaluation. Colloids Surf. B Biointerfaces 2015, 133, 254-262. [CrossRef]

61. Luo, Y.; Zhang, B.; Whent, M.; Yu, L.L.; Wang, Q. Preparation and characterization of zein/chitosan complex for encapsulation of $\alpha$-tocopherol, and its in vitro controlled release study. Colloids Surf. B Biointerfaces 2011, 85, 145-152. [CrossRef]

62. Byun, Y.; Hwang, J.B.; Bang, S.H.; Darby, D.; Cooksey, K.; Dawson, P.L.; Park, H.J.; Whiteside, S. Formulation and characterization of $\alpha$-tocopherol loaded poly e\{open\}-caprolactone (PCL) nanoparticles. LWT Food Sci. Technol. 2011, 44, 24-28. [CrossRef] 
63. Charcosset, C.; Fessi, H. Preparation of nanoparticles with a membrane contactor. J. Memb. Sci. 2005, 266, 115-120. [CrossRef]

64. Singh, P.; Wu, L.; Ren, X.; Zhang, W.; Tang, Y.; Chen, Y.; Carrier, A.; Zhang, X.; Zhang, J. Hyaluronic-acid-based $\beta$-cyclodextrin grafted copolymers as biocompatible supramolecular hosts to enhance the water solubility of tocopherol. Int. J. Pharm. 2020, 586, 119542. [CrossRef] [PubMed]

65. Quintero, C.; Vera, R.; Perez, L.D. $\alpha$-Tocopherol loaded thermosensitive polymer nanoparticles: Preparation, in vitro release and antioxidant properties. Polimeros 2016, 26, 304-312. [CrossRef]

66. Mohammadi, B.; Shekaari, H.; Zafarani-Moattar, M.T. Synthesis of nanoencapsulated vitamin E in phase change material (PCM) shell as thermo-sensitive drug delivery purpose. J. Mol. Liq. 2020, 320, 114429. [CrossRef]

67. Nie, Z.; Liu, K.J.; Zhong, C.J.; Wang, L.F.; Yang, Y.; Tian, Q.; Liu, Y. Enhanced radical scavenging activity by antioxidantfunctionalized gold nanoparticles: A novel inspiration for development of new artificial antioxidants. Free Radic. Biol. Med. 2007, 43, 1243-1254. [CrossRef]

68. Konopko, A.; Kusio, J.; Litwinienko, G. Antioxidant activity of metal nanoparticles coated with tocopherol-like residues-The importance of studies in homo-and heterogeneous systems. Antioxidants 2020, 9, 5. [CrossRef]

69. Dubey, S.; Vyas, S.P. Emulsomes for lipophilic anticancer drug delivery: Development, optimization and in vitro drug release kinetic study. Int. J. Appl. Pharm. 2021, 13, 114-121. [CrossRef]

70. Weber, C.; Weber, T.; Gellert, N.; Schröder, A.; Erl, W.; Neuzil, J.; Terman, A.; Brunk, U.T.; Lu, M.; Coffey, R.J.; et al. Vitamin E succinate is a potent novel antineoplastic agent with high selectivity and cooperativity with tumor necrosis factorrelated apoptosis-inducing ligand (Apo2 ligand) in vivo. Clin. Cancer Res. 2002, 8, 863-869.

71. Angulo-Molina, A.; Méndez-Rojas, M.Á.; Palacios-Hernández, T.; Contreras-López, O.E.; Hirata-Flores, G.A.; Flores-Alonso, J.C.; Merino-Contreras, S.; Valenzuela, O.; Hernández, J.; Reyes-Leyva, J. Magnetite nanoparticles functionalized with $\alpha$-tocopheryl succinate ( $\alpha$-TOS) promote selective cervical cancer cell death. J. Nanoparticle Res. 2014, 16. [CrossRef]

72. Guo, Y.; Luo, J.; Tan, S.; Otieno, B.O.; Zhang, Z. The applications of Vitamin e TPGS in drug delivery. Eur. J. Pharm. Sci. 2013, 49, 175-186. [CrossRef]

73. Yang, C.; Wu, T.; Qi, Y.; Zhang, Z. Recent advances in the application of vitamin E TPGS for drug delivery. Theranostics 2018, 8, 464-485. [CrossRef] [PubMed]

74. Zhang, Z.; Tan, S.; Feng, S.S. Vitamin E TPGS as a molecular biomaterial for drug delivery. Biomaterials 2012, 33, 4889-4906. [CrossRef] [PubMed]

75. Zhang, J.; Muirhead, B.; Dodd, M.; Liu, L.; Xu, F.; Mangiacotte, N.; Hoare, T.; Sheardown, H. An Injectable Hydrogel Prepared Using a PEG/Vitamin E Copolymer Facilitating Aqueous-Driven Gelation. Biomacromolecules 2016, 17, 3648-3658. [CrossRef]

76. Mandracchia, D.; Tripodo, G.; Latrofa, A.; Dorati, R. Amphiphilic inulin-d- $\alpha$-tocopherol succinate (INVITE) bioconjugates for biomedical applications. Carbohydr. Polym. 2014, 103, 46-54. [CrossRef] [PubMed]

77. Mandracchia, D.; Trapani, A.; Perteghella, S.; Sorrenti, M.; Catenacci, L.; Torre, M.L.; Trapani, G.; Tripodo, G. pH-sensitive inulin-based nanomicelles for intestinal site-specific and controlled release of celecoxib. Carbohydr. Polym. 2018, 181, 570-578. [CrossRef]

78. Mandracchia, D.; Rosato, A.; Trapani, A.; Chlapanidas, T.; Montagner, I.M.; Perteghella, S.; Di Franco, C.; Torre, M.L.; Trapani, G.; Tripodo, G. Design, synthesis and evaluation of biotin decorated inulin-based polymeric micelles as long-circulating nanocarriers for targeted drug delivery. Nanomed. Nanotechnol. Biol. Med. 2017, 13, 1245-1254. [CrossRef] [PubMed]

79. Tripodo, G.; Perteghella, S.; Grisoli, P.; Trapani, A.; Torre, M.L.; Mandracchia, D. Drug delivery of rifampicin by natural micelles based on inulin: Physicochemical properties, antibacterial activity and human macrophages uptake. Eur. J. Pharm. Biopharm. 2019, 136, 250-258. [CrossRef] [PubMed]

80. Rassu, G.; Pavan, B.; Mandracchia, D.; Tripodo, G.; Botti, G.; Dalpiaz, A.; Gavini, E.; Giunchedi, P. Polymeric nanomicelles based on inulin D $\alpha$-tocopherol succinate for the treatment of diabetic retinopathy. J. Drug Deliv. Sci. Technol. 2021, 61, 102286. [CrossRef]

81. Tripodo, G.; Chlapanidas, T.; Perteghella, S.; Vigani, B.; Mandracchia, D.; Trapani, A.; Galuzzi, M.; Tosca, M.C.; Antonioli, B.; Gaetani, P.; et al. Mesenchymal stromal cells loading curcumin-INVITE-micelles: A drug delivery system for neurodegenerative diseases. Colloids Surf. B Biointerfaces 2015, 125, 300-308. [CrossRef] [PubMed]

82. Wang, J.; Ma, W.; Guo, Q.; Li, Y.; Hu, Z.; Zhu, Z.; Wang, X.; Zhao, Y.; Chai, X.; Tu, P. The effect of dual-functional hyaluronic acid-vitamin E succinate micelles on targeting delivery of doxorubicin. Int. J. Nanomed. 2016, 11, 5851-5870. [CrossRef]

83. Kaur, K.; Kaur, J.; Kumar, R.; Mehta, S.K. Formulation and physiochemical study of $\alpha$-tocopherol based oil in water nanoemulsion stabilized with non toxic, biodegradable surfactant: Sodium stearoyl lactate. Ultrason. Sonochem. 2017, 38, 570-578. [CrossRef]

84. Lee, C.H.; An, D.S.; Lee, S.C.; Park, H.J.; Lee, D.S. A coating for use as an antimicrobial and antioxidative packaging material incorporating nisin and $\alpha$-tocopherol. J. Food Eng. 2004, 62, 323-329. [CrossRef]

85. Sawicki, T.; Bączek, N.; Starowicz, M. Characterisation of the total phenolic, vitamins $C$ and E content and antioxidant properties of the beebread and honey from the same batch. Czech J. Food Sci. 2020, 38, 158-163. [CrossRef]

86. Lampen, P.; Pittermann, W.; Heise, H.M.; Schmitt, M.; Jungmann, H.; Kietzmann, M. Penetration studies of vitamin E acetate applied from cosmetic formulations to the stratum corneum of an in vitro model using quantification by tape stripping, UV spectroscopy, and HPLC. J. Cosmet. Sci. 2003, 54, 119-131. [PubMed] 
87. Orsavová, J.; Hlaváčová, I.; Mlček, J.; Snopek, L.; Mišurcová, L. Contribution of phenolic compounds, ascorbic acid and vitamin E to antioxidant activity of currant (Ribes L.) and gooseberry (Ribes uva-crispa L.) fruits. Food Chem. 2019, 284, 323-333. [CrossRef] [PubMed]

88. Marcos, B.; Sárraga, C.; Castellari, M.; Kappen, F.; Schennink, G.; Arnau, J. Development of biodegradable films with antioxidant properties based on polyesters containing $\alpha$-tocopherol and olive leaf extract for food packaging applications. Food Packag. Shelf Life 2014, 1, 140-150. [CrossRef]

89. Korchazhkina, O.; Jones, E.; Czauderna, M.; Spencer, S.A.; Kowalczyk, J. HPLC with UV detection for measurement of vitamin E in human milk. Acta Chromatogr. 2006, 16, 48-57.

90. Romeu-Nadal, M.; Morera-Pons, S.; Castellote, A.I.; López-Sabater, M.C. Determination of $\gamma$ - and $\alpha$-tocopherols in human milk by a direct high-performance liquid chromatographic method with UV-vis detection and comparison with evaporative light scattering detection. J. Chromatogr. A 2006, 1114, 132-137. [CrossRef]

91. Delgado Zamarreño, M.M.; Sanchez Ferez, A.; Sanchez Rodriguez, M.; Gomez Ferez, M.C.; Hernandez Mendez, J. Determination of fat-soluble vitamins in yogurt by HPLC with electrochemical detection. Talanta 1996, 43, 1555-1563. [CrossRef]

92. Campanero, M.A.; Calahorra, B.; Garcia-Quetglas, E.; Honorato, J.; Carballal, J.J. Determination of cisapride in human plasma by high-performance liquid chromatography. Chromatographia 1998, 47, 537-541. [CrossRef]

93. Silva, S.D.; Rosa, N.F.; Ferreira, A.E.; Boas, L.V.; Bronze, M.R. Rapid determination of $\alpha$-tocopherol in vegetable oils by fourier transform infrared spectroscopy. Food Anal. Methods 2009, 2, 120-127. [CrossRef]

94. Fuchs-Godec, R.; Zerjav, G. Corrosion resistance of high-level-hydrophobic layers in combination with Vitamin E-( $\alpha$-tocopherol) as green inhibitor. Corros. Sci. 2015, 97, 7-16. [CrossRef]

95. Jović, O.; Habinovec, I.; Galić, N.; Andrašec, M. Maceration of extra virgin olive oil with common aromatic plants using ultrasound-assisted extraction: An uv-vis spectroscopic investigation. J. Spectrosc. 2018, 2018. [CrossRef]

96. Li, X.; Chen, D.; Wang, G.; Lu, Y. Investigation on the interaction between bovine serum albumin and 2,2-diphenyl-1picrylhydrazyl. J. Lumin. 2014, 156, 255-261. [CrossRef]

97. Wang, K.; Sun, D.W.; Wei, Q.; Pu, H. Quantification and visualization of $\alpha$-tocopherol in oil-in-water emulsion based delivery systems by Raman microspectroscopy. LWT 2018, 96, 66-74. [CrossRef]

98. Beattie, J.R.; Maguire, C.; Gilchrist, S.; Barrett, L.J.; Cross, C.E.; Possmayer, F.; Ennis, M.; Elborn, J.S.; Curry, W.J.; McGarvey, J.J.; et al. The use of Raman microscopy to determine and localize vitamin E in biological samples. FASEB J. 2007, 21, 766-776. [CrossRef] [PubMed]

99. Lv, M.Y.; Zhang, X.; Ren, H.R.; Liu, L.; Zhao, Y.M.; Wang, Z.; Wu, Z.L.; Liu, L.M.; Xu, H.J. A rapid method to authenticate vegetable oils through surface-enhanced Raman scattering. Sci. Rep. 2016, 6, 23405. [CrossRef]

100. Tu, Q.; Lin, Z.; Liu, J.; Dai, H.; Yang, T.; Wang, J.; Decker, E.; McClements, D.J.; He, L. Multi-phase detection of antioxidants using surface-enhanced Raman spectroscopy with a gold nanoparticle-coated fiber. Talanta 2020, 206, 120197. [CrossRef]

101. Cai, T.; Gu, H.; Yuan, X.; Liu, F. Normal Raman and SERS spectroscopy of the vitamin E. J. Phys. Conf. Ser. 2011, 277. [CrossRef]

102. Di Mambro, V.M.; Azzolini, A.E.C.S.; Valim, Y.M.L.; Fonseca, M.J.V. Comparison of antioxidant activities of tocopherols alone and in pharmaceutical formulations. Int. J. Pharm. 2003, 262, 93-99. [CrossRef]

103. Berker, K.I.; Ozdemir Olgun, F.A.; Ozyurt, D.; Demirata, B.; Apak, R. Modified Folin-Ciocalteu antioxidant capacity assay for measuring lipophilic antioxidants. J. Agric. Food Chem. 2013, 61, 4783-4791. [CrossRef] [PubMed]

104. Tütem, E.; Apak, R.; Günaydi, E.; Sözgen, K. Spectrophotometric determination of vitamin E ( $\alpha$-tocopherol) using copper(II)neocuproine reagent. Talanta 1997, 44, 249-255. [CrossRef]

105. Martinek, R.G. Method for the Determination of Vitamin E (Total Tocopherols) in Serum. Clin. Chem. 1964, 10, 1078-1086. [CrossRef] [PubMed]

106. Jargar, J.G.; Hattiwale, S.H.; Das, S.; Dhundasi, S.A.; Das, K.K. A modified simple method for determination of serum $\alpha$-tocopherol (Vitamin E). J. Basic Clin. Physiol. Pharmacol. 2012, 23, 45-48. [CrossRef]

107. Golumbic, C.; Mattill, H.A. the Oxidation of Vitamin E. J. Biol. Chem. 1940, 134, 535-541. [CrossRef]

108. Doudin, K.; Al-Malaika, S. Vitamin E-stabilised UHMWPE for orthopaedic implants: Quantitative determination of vitamin E and characterisation of its transformation products. Polym. Degrad. Stab. 2016, 125, 59-75. [CrossRef]

109. Gmbh, T.; Llc, T.; Analytik, I.K. HPLC Method to Determine the Alpha-Tocopherol Content in UHMWPE. In Proceedings of the 55th Annual Meeting of the Orthopaedic Research Society, Las Vegas, NV, USA, 22-25 February 2009. Poster No. 2316.

110. Rowell, S.; Oral, E.; Ok, M. Detection of Vitamin E in Irradiated UHMWPE by UV-Visible Spectroscopy. Chem. Pharm. Bull. 2004, 25, 2434-2439.

111. Martínez-Morlanes, M.J.; Terriza, A.; Yubero, F.; Puértolas, J.A. Characterization of highly crosslinked polyethylenes by colorimetry. Polym. Test. 2012, 31, 841-847. [CrossRef]

112. Gim, S.Y.; Jung, J.; Kwon, Y.J.; Kim, M.J.; Kim, G.H.; Lee, J.H. Effects of chitosan and collagen containing $\alpha$-tocopherol on the oxidative stability in bulk oil and oil-in-water emulsion. Food Sci. Biotechnol. 2018, 27, 947-956. [CrossRef]

113. Stoleru, E.; Munteanu, S.B.; Dumitriu, R.P.; Coroaba, A.; Drobotă, M.; Zemljic, L.F.; Pricope, G.M.; Vasile, C. Polyethylene materials with multifunctional surface properties by electrospraying chitosan/vitamin E formulation destined to biomedical and food packaging applications. Iran. Polym. J. 2016, 25, 295-307. [CrossRef]

114. Salawi, A.; Nazzal, S. The rheological and textural characterization of Soluplus ${ }^{\circledR} /$ Vitamin E composites. Int. J. Pharm. 2018, 546, 255-262. [CrossRef] [PubMed] 
115. Martins, J.T.; Cerqueira, M.A.; Vicente, A.A. Influence of $\alpha$-tocopherol on physicochemical properties of chitosan-based films. Food Hydrocoll. 2012, 27, 220-227. [CrossRef]

116. Sun, Q.; Bi, H.; Wang, Z.; Li, C.; Wang, X.; Xu, J.; Zhu, H.; Zhao, R.; He, F.; Gai, S.; et al. Hyaluronic acid-targeted and $\mathrm{pH}$-responsive drug delivery system based on metal-organic frameworks for efficient antitumor therapy. Biomaterials 2019, 223, 119473. [CrossRef] [PubMed] 